Elsevier required licence: (C) <2019>. This manuscript version is made available under the CC-BY-NCND 4.0 license http://creativecommons.org/licenses/by-nc-nd/4.0/

The definitive publisher version is available online at

[https://www.sciencedirect.com/science/article/pii/S1385894718319338?via\%3Dihub] 


\section{Feasibility study on a double chamber microbial fuel cell for nutrient recovery from municipal wastewater}

Yuanyao Ye ${ }^{\mathrm{a}}$, Huu Hao Ngo ${ }^{\mathrm{a}, \mathrm{d}, *}$, Wenshan Guo ${ }^{\mathrm{a}, \mathrm{d}, *}$, Yiwen Liu ${ }^{\mathrm{a}}$, Soon Woong Chang ${ }^{\mathrm{b}}$, Dinh Duc Nguyen ${ }^{\mathrm{b}}$, Jiawei Ren ${ }^{\mathrm{a}}$, Yi Liuc, Xinbo Zhang ${ }^{\mathrm{d}}$

${ }^{a}$ Centre for Technology in Water and Wastewater, School of Civil and Environmental Engineering, University of Technology Sydney, Sydney, NSW 2007, Australia

${ }^{b}$ Department of Environmental Energy \& Engineering, Kyonggi University, 442-760, Republic of Korea 'Department of Environmental Science and Technology, Fudan University, Shanghai 200433, China

${ }^{d}$ Joint Research Centre for Protective Infrastructure Technology and Environmental Green Bioprocess, School of Environmental and Municipal Engineering, Tianjin Chengjian University, Tianjin 300384, China and School of Civil and Environmental Engineering, University of Technology Sydney, NSW 2007, Australia *Corresponding authors: H. H. Ngo; E-mail address: ngohuuhao121@gmail.com and W. S. Guo: Email address; wguo@uts.edu.au

Abstract

Microbial fuel cell (MFC) is currently considered a promising technology for wastewater treatment. This study aims to evaluate the feasibility of a double-chamber MFC in terms of: (i) operating mode (batch mode, self-circulation mode, single-continuous mode) of anolyte on the nutrient accumulation in the catholyte, (ii) aeration conditions (anode effluent with aeration supplied in catholyte; anode effluent without aeration supplied in catholyte; cathode effluent with aeration supplied in catholyte and cathode effluent without aeration supplied in catholyte) on the nutrient recovery and (iii) types of separators (cation exchange membrane (CEM), forward osmosis (FO), and nonwoven (NW)) to remove nutrients toward their recovery from municipal wastewater. Results showed that there was no negligible increase in the phosphate concentration of the catholyte at the three different modes but accumulation of ammonium. At different aeration conditions, nutrients can be recovered by chemical precipitation at high $\mathrm{pH}$ generated by the MFC itself. Basically, phosphate was removed by microbial absorption and recovered by chemical precipitation while ammonium was accumulated by current generation and recovered as precipitates. It was found that double-chamber MFC with the CEM as the 
separator reported the best nutrients removal with $>97.58 \%$ of $\mathrm{NH}_{4}{ }^{+}-\mathrm{N}$ and $>94.9 \%$ of $\mathrm{PO}_{4}{ }^{3-}-$ $\mathrm{P}$ removed/recovered, followed by the MFC with the nonwoven and FO membrane, respectively. Thus, the double-chamber MFC is feasible for recovering nutrients in a comprehensive bioelectrochemical system.

Keywords: Microbial fuel cell; Nutrient recovery; Municipal wastewater; Chemical precipitation

\section{Introduction}

Phosphorus $(\mathrm{P})$ and nitrogen $(\mathrm{N})$ as nutrients are responsible for several serious environmental problems such as eutrophication in water bodies, especially if both are in quantities in the aquatic environment. In water, $\mathrm{P}$ and $\mathrm{N}$ exist in phosphate and ammonium ions, respectively. It should be noted here that phosphate and ammonium are also essential to plants and crops in agriculture and always used for direct land application in the form of chemical fertilizers. Phosphate as the nonrenewable resource is mainly derived from natural phosphate-based rocks, but it has been estimated that the global phosphate deposits will completely run out in 30-300 years [1]. This means the production of phosphate-based fertilizers will end at some point. More importantly, the role of phosphate in the fertilizer production will not be replaced by any other materials [2].

Ammonium utilized for the purposes of fertilizer production is usually achieved through the industrial Haber-Bosch process via the conversion of nitrogen gas in the atmosphere to reactive ammonium [3]. However, this process is energy-intensive and its excessive application may disturb the natural N-cycle and hence cause problems for the environment and people. For this reason, nutrient recovery is more valuable than nutrient removal because 
it does not only minimize the pollution risk to receiving waters; also it contributes to sustainable resource management $[4,5]$. Currently, the concept of municipal wastewater and its treatment has shifted from a human health concern and environmental hazard to one where it is considered to be an untapped source. Firstly, it contains a large amount of valuable components such as nutrients (phosphate and ammonium ions), heavy metals, fresh water and chemical energy stored in the organics. Secondly, it exists in large quantities [6].

Understandably, recovering nutrients from municipal wastewater is a promising research approach with a practical benefit. Several methods including adsorption, chemical precipitation and biological processes have been developed or are still in the development stage for nutrients recovery from municipal wastewater [7-10]. For example, biological processes such as an enhanced biological phosphorus removal system can efficiently recover nutrients in the form of excessive sludge. However, the surplus sludge contains toxic substances and pathogens [11], so this method has been banned for direct land application in some European countries such as Switzerland [12].

Even though the effective recovery of $\mathrm{N}$ and $\mathrm{P}$ could be obtained via adsorption, the desorption of nutrient-loaded adsorbents may be required to achieve the desired recovered nutrients. As for nutrients recovery through chemical precipitation, this has been deemed one of the most promising methods due to its high stability and efficiency. In this scenario, magnesium and calcium materials are usually utilized as the precipitator. Struvite $\left(\mathrm{MgNH}_{4} \mathrm{PO}_{4} \cdot 6 \mathrm{H}_{2} \mathrm{O}\right)$ employed in stoichiometric precipitation of magnesium, ammonium and phosphate has proved to be an efficient fertilizer when directly applied in agriculture [13-17]. Similarly, calcium can react with phosphate to form hydroxyapatite $\left(\mathrm{Ca}_{5}[\mathrm{OH}]\left[\mathrm{PO}_{4}\right]_{3}, \mathrm{HAP}\right)$ 
which also works as an efficient fertilizer supplement. The reaction between nutrient and magnesium/calcium ions could be described as follows:

$$
\begin{aligned}
& \mathrm{Mg}^{2+}+\mathrm{PO}_{4}^{3-}+\mathrm{NH}_{4}^{+}+6 \mathrm{H}_{2} \mathrm{O} \rightarrow \mathrm{MgNH}_{4} \mathrm{PO}_{4} \cdot 6 \mathrm{H}_{2} \mathrm{O} \downarrow(1) \\
& 5 \mathrm{Ca}^{2+}+3 \mathrm{PO}_{4}^{3-}+3 \mathrm{OH}^{-} \rightarrow \mathrm{Ca}_{5}(\mathrm{OH})\left(\mathrm{PO}_{4}\right)_{3} \downarrow(2)
\end{aligned}
$$

The chemical precipitation requires high $\mathrm{pH}(>8)$, for which the $\mathrm{pH}$ value is the most important influencing factor. More importantly, the chemicals added to increase the $\mathrm{pH}$, could represent a high percentage of the cost of the nutrient recovery process [18-20].

Microbial fuel cell (MFC) is currently considered a promising technology in the wastewater treatment due to its production of electricity and wastewater purification [21, 22]. Typically, the MFC has an anode chamber and a cathode chamber, respectively, and a cationexchange membrane (CEM) is installed to separate the two chambers. In the anode chamber, the anaerobic microorganisms are catalysts that convert chemical energy stored in organics directly into electricity $[23,24]$. MFC can use sewage sludge as a substrate, which is considered a kind of biomass $[25,26]$. Recently, nutrients recovery through the MFC process has attracted much attention $[4,5,8]$ since the $\mathrm{pH}$ value of electrolyte can be raised without adding alkaline chemicals $[27,28]$. In this scenario, the costs of $\mathrm{pH}$ adjustment can be reduced. Furthermore, the energy recovered in the MFC may be used for its own operation and maintenance, which indicates that the MFC may be a neutral/positive energy balance system.

The single- and double-chamber MFCs constitute the most common types of MFC. Recently, the single-chamber MFC with an air-cathode electrode and multi-chamber MFC coupled with CEMs and/or anion-exchange membranes (AEMs) have been developed for 
recovering nutrients from wastewater [2, 29-31]. For example, Chen et al. [29] proposed a new MFC that simultaneously uses CEMs and AEMs to recover nutrients and purify wastewater. In their study, wastewater was circulated between the anode and cathode chambers and this particular configuration facilitated nutrient accumulation. According to their findings, the concentrations of ammonium and phosphate ions were condensed to 1.5 and 2.2 of their initial concentrations. This caused the removal of $>64 \%$ of $\mathrm{PO}_{4}{ }^{3-}-\mathrm{P}$ and $96 \%$ of $\mathrm{NH}_{4}^{+}-\mathrm{N}$.

Even though the single-chamber MFC could reduce the overall operating costs to some extent, integrating the anolyte and catholyte may buffer the $\mathrm{pH}$ of electrolyte and thus inhibit the $\mathrm{pH}$ elevation of the electrolyte. Referring to the multi-chamber MFC, using several chambers may increase the maintenance costs and operation complexity. However, a very few articles have studied on nutrient recovery using a conventional double-chamber MFC.

This paper investigated the feasibility of the conventional double-chamber MFC for nutrient recovery from municipal wastewater. The concentrations of $\mathrm{NH}_{4}{ }^{+}-\mathrm{N}, \mathrm{PO}_{4}{ }^{3-}-\mathrm{P}$ and COD along the treatment process and the recovery process were evaluated. Furthermore, the sediment deposits in the cathode chamber were analysed by energy dispersive spectroscopy (EDS) and scanning electron microscopy (SEM). More importantly, a new design of doublechamber MFC with the forward osmosis (FO) membrane or nonwoven as the separator was also evaluated.

\section{Materials and method}

\subsection{MFC construction}

The double-chamber MFC was made of organic glass (i.e., poly[methyl methacrylate]) and consisted of an anode chamber and a cathode chamber in a rectangular form. The 
effective liquid volumes of each chamber were both $350 \mathrm{~mL}$. A CEM (CMI7000, Membranes International Inc., USA) was used to separate the anode chamber and cathode chamber. A cylinder-shaped graphite felt (Sanye Carbon Co. Ltd., Beijing, China) $3 \mathrm{~cm}$ in diameter and $0.6 \mathrm{~cm}$ in thickness served as the anode electrode in the double-chamber MFC to hold the electrically active biofilms. The cathode electrode was made of a carbon-fiber brush $(\sim 3 \mathrm{~cm}$ in length and $\sim 3 \mathrm{~cm}$ in diameter) coated with a titanium bar. The anode electrode and cathode electrode were placed on opposite sides of the CEM and connected by a copper wire.

Moreover the external circuit contained an external resistance of $1000 \Omega$.

\subsection{Microorganisms and synthetic wastewater}

The anaerobic sludge inoculated in the anode chamber was collected from the Cronulla wastewater treatment plant in New South Wales, Australia, and cultured for 6 months before starting the experiments. Meanwhile the concentration of dissolved oxygen (DO) in the anode chamber was controlled at $0.02 \pm 0.01 \mathrm{mg} / \mathrm{L}$. The electrolyte (i.e. synthetic wastewater) in the anode chamber imitated typical municipal wastewater, containing (per liter in Milli-Q water) the following: $0.3 \mathrm{~g}$ glucose, $0.0046 \mathrm{~g} \mathrm{KH}_{2} \mathrm{PO}_{4}, 0.02 \mathrm{~g} \mathrm{NH} 4 \mathrm{Cl}, 0.0054 \mathrm{~g} \mathrm{MgSO} \cdot 7 \mathrm{H}_{2} \mathrm{O}$, $0.0004 \mathrm{~g} \mathrm{CaCl}_{2} \cdot 2 \mathrm{H}_{2} \mathrm{O}, 0.032 \mathrm{~g}$ yeast and $0.61 \mathrm{~mL}$ of trace nutrients. All experiments studied in this paper were conducted using the same synthetic wastewater, in which the measured concentrations of COD, $\mathrm{NH}_{4}{ }^{+}-\mathrm{N}$ and $\mathrm{PO}_{4}{ }^{3-}-\mathrm{P}$ were $300 \pm 15,5.0 \pm 0.15$ and $1.0 \pm 0.05 \mathrm{mg} / \mathrm{L}$, respectively. The cathode chamber was filled with distilled water (DI water) which was prepared in the laboratory.

\subsection{Experimental process}

A bottle containing $1000 \mathrm{~mL}$ of the synthetic wastewater was pumped using a peristaltic pump (Model 77202-60, Masterflex, Illinois, United States) into the anode chamber of the double-chamber MFC. The initial $\mathrm{pH}$ values of the synthetic wastewater were adjusted to $7.00 \pm 0.1$ by adding hydrochloric acid $(\mathrm{HCl})$ and sodium hydroxide $(\mathrm{NaOH})$ solutions. The 
double-chamber MFC was firstly conducted at different operating modes of the anolyte at room temperature $\left(\sim 25^{\circ} \mathrm{C}\right)$, in order to examine the nutrients' accumulation in the catholyte. As shown in Fig. 1, the synthetic wastewater in the anode chamber of the MFC functioned in three ways: (a) it was pumped into the anode chamber and kept unchanged for $24 \mathrm{~h}$, and then replaced by the fresh synthetic wastewater (called the batch mode); (b) it was pumped into the anode chamber and then circulated within the anode chamber at a given flow rate of $10 \mathrm{~mL} / \mathrm{min}$ and then renewed every $24 \mathrm{~h}$ (known as the self-circulation mode); and (c) it was pumped to flow through the anode chamber at a fixed flow rate of $0.24 \mathrm{~mL} / \mathrm{min}$, which indicated the hydraulic retention time of the anode chamber was $24 \mathrm{~h}$ (referred to as the single-continuous mode). In these three modes, the DI water served as the catholyte and the cathode chamber was conducted in the absence of aeration.

Then the anode chamber was connected to the cathode chamber as described in Fig. 2 to explore the performance of nutrient recovery in the cathode chamber. In this scenario, the effluent from the anode chamber was used as the influent for the cathode chamber. Thus, the synthetic wastewater was sequentially treated in two steps in the double-chamber MFC: firstly, treated by anaerobic microorganisms for removing organics and recovering energy in the anode chamber; and secondly, conducted directional ion migration to recover phosphorus and nitrogen in the cathode chamber. In this study, the cathode chamber was conducted with and without air supply, respectively, to determine the effects of aeration for catholyte on the nutrient recovery.

Alternatively, this process was conducted in the scenario where the FO membrane (Toray Chemical Korea Inc.) and nonwoven with a thickness of $0.75 \mathrm{~mm}$ (Dongguan Jia Lianda Nonwoven Co., Ltd. Dongguan, China) were utilized to replace the CEM as the separator of the double-chamber MFC. This experiment was performed while applying aeration in the cathode chamber. 


\subsection{Analysis method}

Effluent samples collected from the anode and cathode chambers were filtered by a 0.45- $\mu \mathrm{m}$ membrane filter (Tianjin Jinteng Experimental Equipment Co. Ltd., Tianjin, China) and then utilized for later measurement. The concentrations of $\mathrm{NH}_{4}{ }^{+}-\mathrm{N}$ and $\mathrm{PO}_{4}{ }^{3-}-\mathrm{P}$ were tested through the spectrophotometric method using Spectroquant ${ }^{\circledR}$ Test Kits (NOVA 60, Merck). The COD concentration was measured based on the Standard Methods [32]. The $\mathrm{pH}$ values were monitored by a pH meter (hi9025, Hanna instruments, Limena, Italy) while the DO concentrations were tested by a DO meter (OM-51, Horiba, Tokyo, Japan). Moreover, the sediment deposits achieved within the MFC were first collected and stored in a beaker, after which they were washed by Milli-Q water three times at least in order to remove soluble chemicals from their surface. The mixture was then centrifuged at $3000 \mathrm{rpm}$ for $20 \mathrm{~min}$ and the supernatant was dried at $105{ }^{\circ} \mathrm{C}$ in an oven for $12 \mathrm{~h}$. The resulting, dried precipitates were characterized through SEM coupled with EDS to examine the morphology and elemental composition. The cell voltage $(U)$ over an external resistance $(R, 1000 \Omega)$ was recorded using different time intervals throughout the operation period.

\section{Results and discussions}

\subsection{Effects of operation mode of anolyte on the nutrient accumulation in the catholyte}

The effects of operation mode of anolyte on the nutrient accumulation were studied at three conditions as described in Fig. 1: (a) batch mode; (b) self-circulation mode; and (c) single-continuous mode. The phosphorus and nitrogen exist as $\mathrm{NH}_{4}{ }^{+}-\mathrm{N}$ and $\mathrm{PO}_{4}{ }^{3-}-\mathrm{P}$, respectively in the synthetic wastewater and their concentrations in the cathode chamber were monitored as a function of operation time (Fig. 3). It should be noted here that the initial concentrations of $\mathrm{NH}_{4}{ }^{+}-\mathrm{N}$ and $\mathrm{PO}_{4}{ }^{3-}-\mathrm{P}$ in the catholyte (i.e. DI water) were close to zero. From Fig. 3, it could be seen that the concentration of $\mathrm{NH}_{4}{ }^{+}-\mathrm{N}$ in the catholyte gradually increased after fresh synthetic wastewater was fed into the anode chamber no matter what the 
operation modes of the anolyte were. This may be attributed to the pathway of the ammonium transfer across the CEM from the anode chamber to the cathode chamber in the doublechamber MFC. Generally, the ammonium transfer mainly relies on two processes: diffusion and migration. Specifically, diffusion is caused by the ammonium concentration gradient between the anolyte and catholyte while migration is driven by the current field generated by the MFC.

More importantly, the ammonium diffusion depends on the ammonium concentration gradient and may reach equilibrium with decreasing concentration gradient; in contrast, the ammonium migration driven by the electricity is against the concentration gradient. As result of this, the ammonium concentration in the catholyte could gradually increase with running time through the ammonium migration if the MFC could continuously and effectively generate electricity. Specifically, the concentration of $\mathrm{NH}_{4}{ }^{+}-\mathrm{N}$ increased to 5.9, 4.6 and 4.2 $\mathrm{mg} / \mathrm{L}$, respectively, after running the double-chamber for $30 \mathrm{~d}$ at the self-circulation mode, single-continuous mode and batch mode, respectively. The ammonium transfer across the CEM in the MFC was also observed in other studies $[33,34]$. The difference in the increased ammonium concentrations may be ascribed to the efficiency of energy recovery in the MFC. Results showed that the self-circulation mode of the MFC could generate the maximum voltage of $641.4 \mathrm{mV}$ while the maximum voltages created in the batch and single-continuous modes were $386.4 \mathrm{mV}$ and $591.9 \mathrm{mV}$, respectively. This indicated that the self-circulation mode better facilitated the effective exposure of anaerobic microorganisms to the synthetic wastewater and thus increased the generation of electrons.

As for the phosphate ions, there was no negligible increase in the phosphate concentration of the catholyte at the three different modes. This is because the phosphate ions as the anions were not allowed to transfer across the CEM.

\subsection{Effects of aeration on the nutrient recovery}


As discussed in Section 3.1, whatever the operation of the anolyte changed may only lead to the accumulation of ammonium in the catholyte. Thus, the operation mode of MFC was present as described in Fig. 2 to investigate the recovery performance and concentrating extent of $\mathrm{NH}_{4}{ }^{+}-\mathrm{N}$ and $\mathrm{PO}_{4}{ }^{3-}-\mathrm{P}$. The synthetic wastewater was pumped to the anode chamber at a given volumetric flow rate of $0.35 \mathrm{~mL} / \mathrm{min}$ and the anode effluent was utilized as the cathode influent. In this study, the MFC cathode was operated as either aeration (oxygen reduction) or no aeration, where the DO concentration in the cathode chamber was controlled at $6.22 \pm 0.10 \mathrm{mg} / \mathrm{L}$ in the presence of aeration. The changes in the concentrations of $\mathrm{NH}_{4}{ }^{+}-\mathrm{N}$ and $\mathrm{PO}_{4}{ }^{3-}-\mathrm{P}$ are plotted in Figure 4.

As shown in the Fig. 4, the concentrations of $\mathrm{NH}_{4}{ }^{+}-\mathrm{N}$ and $\mathrm{PO}_{4}{ }^{3-}-\mathrm{P}$ decreased slightly in the anode effluent whether the aeration was supplied in the cathode chamber or not. The reduction in the concentrations of $\mathrm{NH}_{4}{ }^{+}-\mathrm{N}$ and $\mathrm{PO}_{4}{ }^{3-}-\mathrm{P}$ ranged from 0.8 to $1.5 \mathrm{mg} / \mathrm{L}$ and 0.07 to $0.20 \mathrm{mg} / \mathrm{L}$, respectively. This may be attributed to the biological activity of microorganisms required for their growth. Moreover, this decline indicated that the aeration used in the cathode chamber negligibly influenced the removal behavior of $\mathrm{NH}_{4}{ }^{+}-\mathrm{N}$ and $\mathrm{PO}_{4}{ }^{3-}$ $-\mathrm{P}$ in the anode chamber. In contrast, the concentrations of $\mathrm{NH}_{4}{ }^{+}-\mathrm{N}$ and $\mathrm{PO}_{4}{ }^{3-}-\mathrm{P}$ in the cathode effluent greatly reduced while supplying aeration in the cathode chamber. The possible reason for this is that most ammonium and phosphate ions were removed by chemical precipitation. In the double-chamber MFC, the electrons generated in the anode chamber transferred along the external circuit to the cathode electrode, and then reacted with oxygen to form the hydroxyl ions. The anode and cathode reactions in this study are described in Equations (3) and (4).

Anode reaction: $\mathrm{C}_{6} \mathrm{H}_{12} \mathrm{O}_{6}+6 \mathrm{H}_{2} \mathrm{O} \rightarrow \mathrm{CO}_{2} \uparrow+24 \mathrm{H}^{+}+24 \mathrm{e}^{-}(3)$

Cathode reaction: $2 \mathrm{H}_{2} \mathrm{O}+\mathrm{O}_{2}+4 \mathrm{e}^{-} \rightarrow 4 \mathrm{OH}^{-}(4)$

From Eq. (4), the $\mathrm{pH}$ that was localized the cathode electrode increased while aeration 
was supplied in the cathode chamber. In this study, the $\mathrm{pH}$ of catholyte ranged from 8.0-8.4 in the presence of aeration in the cathode chamber, which facilitated the ammonium and phosphate precipitating with magnesium and/or calcium ions. By contrast, although a multichamber MFC could efficiently enrich the nutrients [35], additional $\mathrm{NaOH}$ is needed to elevate the solution $\mathrm{pH}$ in the precipitation process [36]. Similarly, many other studies also reported that effective nutrient recovery by chemical precipitation requires alkaline condition $[37,38]$.

It could be seen from Fig. 4 that the average concentrations of $\mathrm{NH}_{4}{ }^{+}-\mathrm{N}$ and $\mathrm{PO}_{4}^{3-}-\mathrm{P}$ ions decreased to around 0.20 and $0.05 \mathrm{mg} / \mathrm{L}$, respectively. Moreover, the removal of a partial amount of ammonium may be attributed to air stripping. To investigate how big the role of air stripping and chemical precipitation for the ammonium removal/recovery was in the process, the anode effluent was collected and performed in two different pathways. Firstly, the $\mathrm{pH}$ of anode effluent was increased to 8.1-8.4 using $\mathrm{NaOH}$ solution in the absence of aeration. Alternatively, the air stripping was utilized for the anode effluent without the $\mathrm{pH}$ elevation. Results suggested that either the $\mathrm{pH}$ increase of anode effluent or air stripping for the anode effluent could result in more than $97 \%$ of $\mathrm{NH}_{4}{ }^{+}-\mathrm{N}$ removed/recovered. This also indicated that the ammonium recovery/removal in the double-chamber MFC was achieved through the combined effects of chemical precipitation and air stripping. In contrast, any changes in the concentrations of ammonium and phosphate between the anode effluent and cathode effluent were insignificant when the cathode chamber was conducted in the absence of aeration. This is because the $\mathrm{pH}$ of catholyte ranged from 7.5 to 7.8 in this scenario and such $\mathrm{pH}$ values thereby could not lead to the formation of the nutrient-based precipitates.

In addition, the sediments deposited on the cathode surface and in the catholyte were analyzed by the SEM and EDS after running the double-chamber MFC for $26 \mathrm{~d}$. As shown in the SEM image (Fig. 5b), some crystals could be seen. Besides, the EDS was applied to 
detect the elemental compositions of the precipitates and demonstrated that $\mathrm{C}, \mathrm{K}, \mathrm{Ca}, \mathrm{N}, \mathrm{O}$ $\mathrm{Na}, \mathrm{Mg}$ and $\mathrm{P}$ were the main elements detected (Fig. 5a) and such elemental composites are quite similar to elements of the pure struvite standards [39]. Many investigations in nutrient recovery via chemical precipitation from wastewater observed an inadequate amount of $\mathrm{Mg}^{2+}$ $[40,41]$ and additional $\mathrm{Mg}^{2+}$ sources are therefore needed such as water-soluble $\mathrm{Mg}$ salts and $\mathrm{MgO}[20,42]$. This undoubtedly increases the overall costs, but the present study achieved the nutrients-based precipitates without magnesium input.

Nevertheless, further research is needed to compare the precipitates achieved in this study to the chemical struvite in terms of the fertilizer's efficacy for crops and plants. Moreover, a small quantity of $\mathrm{P}$ observed in the EDS may be attributed to the relatively low phosphate concentration in the influent and short running time.

In the precipitates, the phosphorus accounts for $2.6 \%$ of the total weight of precipitates, leading to the mass balance of $\mathrm{PO}_{4}^{3-}-\mathrm{P}$ being studied after running the MFC for $26 \mathrm{~d}$.

Theoretical total mass of $\mathrm{PO}_{4}-\mathrm{P}$ in the influent:

$1 \mathrm{mg} / \mathrm{L} \times 0.35 \mathrm{~mL} / \mathrm{min} \times 60 \mathrm{~min} \times 24 \times 26\left(\right.$ operation period) $\times 10^{-3}=13.104 \mathrm{mg}$

Experimental total mass of $\mathrm{PO}_{4}{ }^{3-}-\mathrm{P}$ in the anode effluent:

$11.491 \mathrm{mg}$

Experimental total mass of $\mathrm{PO}_{4}{ }^{3-}-\mathrm{P}$ loss in the cathode chamber:

$10.902 \mathrm{mg}$

Theoretical total mass of phosphorus recovered:

$417.6 \mathrm{mg}$ (the precipitates weight) $\times 2.6 \%=10.842 \mathrm{mg}$

According to the analysis, $>94 \%$ of phosphorus was recovered in the conventional double-chamber MFC. It could be observed some differences emerged between the experimental loss of $\mathrm{PO}_{4}{ }^{3-}-\mathrm{P}(10.902 \mathrm{mg})$ and the theoretical loss $(10.842 \mathrm{mg})$, which may be attributed to the unavoidable loss during the analysis of the precipitates. 


\subsection{Effects of different separators in the MFC on nutrient recovery}

As discussed in Section 3.2, the MFC where the CEM was used as the separator could achieve effective nutrients recovery and removal. In the recovery process, the role of CEM was to avoid the direct transfer of anions and facilitate the direct transfer of protons from the anolyte to catholyte, both of which was beneficial to the $\mathrm{pH}$ elevation of catholyte and further nutrient recovery by chemical precipitation. In this section, the FO membrane and nonwoven were used to replace the role of CEM in the double-chamber MFC to identify their effects on the nutrient recovery. The new MFC was conducted using the same process as described in Fig. 2.

As shown in Fig. 6, the double-chamber MFC with the CEM as the separator reported the best nutrients removal with $>97.58 \%$ of $\mathrm{NH}_{4}{ }^{+}-\mathrm{N}$ and $>94.9 \%$ of $\mathrm{PO}_{4}{ }^{3-}-\mathrm{P}$ removed/recovered, followed by the MFC with the nonwoven and FO membrane, respectively. This is because the transfer of cations across the CEM may facilitate an increase in the $\mathrm{pH}$ of catholyte due to maintaining charge neutrality of catholyte. Similarly, the proton consumption for the cathode reaction (i.e. oxygen reduction reaction) plays the same role for increasing $\mathrm{pH}$. Referring to the FO membrane being used as the separator, the MFC could remove $98.81 \%$ of $\mathrm{NH}_{4}{ }^{+}-\mathrm{N}$ and $83.18 \%$ of $\mathrm{PO}_{4}{ }^{3-}-\mathrm{P}$ because $\mathrm{pH}$ value of catholyte which was over 8.0 facilitated nutrients recovery through chemical precipitation. Previously, Zhang et al. [43] proposed an osmotic MFC with the installment of an FO membrane between the anode and cathode and found that this osmotic MFC could generate higher electrical current than that achieved in a conventional MFC containing CEM, while applying the $\mathrm{NaCl}$ solution as a catholyte/draw solution. This may be attributed to the enhanced proton transport with water flux and smaller membrane resistance.

In this study, however, the efficiency of phosphate removal achieved in the osmotic MFC was lower than that obtained in the conventional MFC with the CEM as the separator. A possible explanation for this is that some anions in the anolyte diffused to the cathode 
chamber and thus inhibited the $\mathrm{pH}$ elevation of the catholyte. Consequently, the recovery of nutrients via chemical precipitation was weakened. Similarly, the ions in the catholyte and anolyte may also freely transfer across the nonwoven and the $\mathrm{pH}$ increase of catholyte was thereby constrained. Nevertheless, the removal efficiency of $\mathrm{NH}_{4}{ }^{+}-\mathrm{N}$ and of $\mathrm{PO}_{4}{ }^{3-}-\mathrm{P}$ could reach $97.2 \%$ and $90.6 \%$, respectively, while using the nonwoven as the separator of the double-chamber MFC. Similarly, Ichihashi and Hirooka [2] also used nonwoven as a separator in an air-cathode MFC, which achieved the removal of $70-82 \%$ of phosphorus. In addition, the average COD removal efficiencies in the three MFCs with CEM, FO membrane and nonwoven were over $81.19 \%$. Compared to the MFC with FO membrane, the one with CEM and nonwoven as the separator showed higher removal efficiency of COD. The results also indicated that the MFCs with different separators studied above had good performance for the wastewater purification.

\section{Conclusion}

In this study, the double-chamber MFC could effectively remove $\mathrm{NH}_{4}{ }^{+}-\mathrm{N}$ and of $\mathrm{PO}_{4}{ }^{3-}-\mathrm{P}$ from wastewater for recovery. The MFC could only obtain effective ammonium accumulation in the cathode chamber if the anode chamber was not connected to the cathode chamber. Apart from this, the ammonium transfer from the anolyte to catholyte was mainly driven by the electrical field derived from energy recovery from wastewater, especially in the later running time. Phosphorus and nitrogen were removed by the combined effect of chemical precipitation and microbial absorption while wastewater was sequentially treated by the anode chamber and cathode chamber. Moreover, partial nitrogen was removed through air stripping. Through an analysis of the precipitates formed in the cathode chamber, the main elements in the mixture included phosphorus, nitrogen, magnesium, calcium and hydroxyl compound. When the FO membrane and NW were used as a separator in the double-chamber 
MFC, the efficiency in removing $\mathrm{NH}_{4}{ }^{+}-\mathrm{N}$ and of $\mathrm{PO}_{4}{ }^{3-}-\mathrm{P}$ was inferior to that observed in the conventional MFC.

\section{Acknowledgements}

This research was supported by the Centre for Technology in Water and Wastewater, University of Technology, Sydney (UTS, RIA NGO) and Joint Research Centre for

Protective Infrastructure Technology and Environmental Green Bioprocess (UTS and Tianjin Chengjian University).

\section{References}

[1] J. Elser, E. Bennett, Phosphorus cycle: a broken biogeochemical cycle, Nature, 478 (2011) 29-31.

[2] O. Ichihashi, K. Hirooka, Removal and recovery of phosphorus as struvite from swine wastewater using microbial fuel cell, Bioresour. Technol., 114 (2012) 303-307.

[3] H. Gong, Z. Wang, X. Zhang, Z. Jin, C. Wang, L. Zhang, K. Wang, Organics and nitrogen recovery from sewage via membrane-based pre-concentration combined with ion exchange process, Chem. Eng. J., 311 (2017) 13-19.

[4] T. Yan, Y. Ye, H. Ma, Y. Zhang, W. Guo, B. Du, Q. Wei, D. Wei, H.H. Ngo, A critical review on membrane hybrid system for nutrient recovery from wastewater, Chem. Eng. J., 348 (2018) 143-156.

[5] Y. Nancharaiah, S.V. Mohan, P. Lens, Recent advances in nutrient removal and recovery in biological and bioelectrochemical systems, Bioresour. Technol., 215 (2016) 173-185.

[6] W. Xue, T. Tobino, F. Nakajima, K. Yamamoto, Seawater-driven forward osmosis for enriching nitrogen and phosphorous in treated municipal wastewater: Effect of membrane 
properties and feed solution chemistry, Water Res., 69 (2015) 120-130.

[7] Y. Ye, Y. Hu, Z. Hussain, X. Li, D. Li, J. Kang, Simultaneous adsorptive removal of fluoride and phosphate by magnesia-pullulan composite from aqueous solution, RSC Adv, 6 (2016) 35966-35976.

[8] P.T. Kelly, Z. He, Nutrients removal and recovery in bioelectrochemical systems: a review, Bioresour. Technol., 153 (2014) 351-360.

[9] S.M. Iskander, B. Brazil, J.T. Novak, Z. He, Resource recovery from landfill leachate using bioelectrochemical systems: Opportunities, challenges, and perspectives, Bioresour. Technol., 201 (2016) 347-354.

[10] Y. Ye, H.H. Ngo, W. Guo, Y. Liu, J. Li, Y. Liu, X. Zhang, H. Jia, Insight into chemical phosphate recovery from municipal wastewater, Sci. Total Environ., 576 (2017) 159-171.

[11] Y. Ye, H.H. Ngo, W. Guo, Y. Liu, X. Zhang, J. Guo, B.-j. Ni, S.W. Chang, D.D. Nguyen, Insight into biological phosphate recovery from sewage, Bioresour. Technol., 218 (2016) 874-881.

[12] O.F. Schoumans, F. Bouraoui, C. Kabbe, O. Oenema, K.C. Van Dijk, Phosphorus management in Europe in a changing world, Ambio, 44 (2015) 180-192.

[13] S. Johansson, M. Ruscalleda, J. Colprim, Phosphorus recovery through biologically induced precipitation by partial nitritation-anammox granular biomass, Chem. Eng. J., 327 (2017) 881-888.

[14] S. Kataki, H. West, M. Clarke, D. Baruah, Phosphorus recovery as struvite: Recent concerns for use of seed, alternative $\mathrm{Mg}$ source, nitrogen conservation and fertilizer potential, Resour. Conserv. Recy., 107 (2016) 142-156. 
[15] E. Desmidt, K. Ghyselbrecht, Y. Zhang, L. Pinoy, B. Van der Bruggen, W. Verstraete, K. Rabaey, B. Meesschaert, Global phosphorus scarcity and full-scale P-recovery techniques: a review, Crit. Rev. Environ. Sci. Technol., 45 (2015) 336-384.

[16] D. Mitrogiannis, M. Psychoyou, I. Baziotis, V.J. Inglezakis, N. Koukouzas, N. Tsoukalas, D. Palles, E. Kamitsos, G. Oikonomou, G. Markou, Removal of phosphate from aqueous solutions by adsorption onto $\mathrm{Ca}(\mathrm{OH})_{2}$ treated natural clinoptilolite, Chem. Eng. J., 320 (2017) 510-522.

[17] X. Hao, C. Wang, M.C. van Loosdrecht, Y. Hu, Looking beyond struvite for P-recovery, in, ACS Publications, 2013.

[18] Y. Jaffer, T. Clark, P. Pearce, S. Parsons, Potential phosphorus recovery by struvite formation, Water Res., 36 (2002) 1834-1842.

[19] S.G. Barbosa, L. Peixoto, B. Meulman, M.M. Alves, M.A. Pereira, A design of experiments to assess phosphorous removal and crystal properties in struvite precipitation of source separated urine using different Mg sources, Chem. Eng. J., 298 (2016) 146-153. [20] H. Huang, Y. Chen, Y. Jiang, L. Ding, Treatment of swine wastewater combined with MgO-saponification wastewater by struvite precipitation technology, Chem. Eng. J., 254 (2014) 418-425.

[21] L. Deng, H.-H. Ngo, W. Guo, J. Wang, H. Zhang, Evaluation of a new sponge additionmicrobial fuel cell system for removing nutrient from low $\mathrm{C} / \mathrm{N}$ ratio wastewater, Chem. Eng. J., (2018).

[22] V. Ortiz-Martínez, M. Salar-García, A. De Los Ríos, F. Hernández-Fernández, J. Egea, L. Lozano, Developments in microbial fuel cell modeling, Chem. Eng. J., 271 (2015) 50-60. 
[23] B.E. Logan, B. Hamelers, R. Rozendal, U. Schröder, J. Keller, S. Freguia, P. Aelterman, W. Verstraete, K. Rabaey, Microbial fuel cells: methodology and technology, Environ. Sci. Technol., 40 (2006) 5181-5192.

[24] Z. Yang, H. Pei, Q. Hou, L. Jiang, L. Zhang, C. Nie, Algal biofilm-assisted microbial fuel cell to enhance domestic wastewater treatment: Nutrient, organics removal and bioenergy production, Chem. Eng. J., 332 (2018) 277-285.

[25] Y. Chen, J. Luo, Y. Yan, L. Feng, Enhanced production of short-chain fatty acid by cofermentation of waste activated sludge and kitchen waste under alkaline conditions and its application to microbial fuel cells, ApEn, 102 (2013) 1197-1204.

[26] C. Abourached, K.L. Lesnik, H. Liu, Enhanced power generation and energy conversion of sewage sludge by CEA-microbial fuel cells, Bioresour. Technol., 166 (2014) 229-234.

[27] A. Colombo, S. Marzorati, G. Lucchini, P. Cristiani, D. Pant, A. Schievano, Assisting cultivation of photosynthetic microorganisms by microbial fuel cells to enhance nutrients recovery from wastewater, Bioresour. Technol., 237 (2017) 240-248.

[28] F. Zhao, F. Harnisch, U. Schröder, F. Scholz, P. Bogdanoff, I. Herrmann, Challenges and constraints of using oxygen cathodes in microbial fuel cells, Environ. Sci. Technol., 40 (2006) 5193-5199.

[29] X. Chen, D. Sun, X. Zhang, P. Liang, X. Huang, Novel self-driven microbial nutrient recovery cell with simultaneous wastewater purification, Sci. Rep., 5 (2015) 15744.

[30] Y.-K. Geng, Y. Wang, X.-R. Pan, G.-P. Sheng, Electricity generation and in situ phosphate recovery from enhanced biological phosphorus removal sludge by electrodialysis membrane bioreactor, Bioresour. Technol., 247 (2018) 471-476. 
[31] L. Damiano, J.R. Jambeck, D.B. Ringelberg, Municipal solid waste landfill leachate treatment and electricity production using microbial fuel cells, Appl. Biochem. Biotechnol., 173 (2014) 472-485.

[32] W.E. Federation, A.P.H. Association, Standard methods for the examination of water and wastewater, American Public Health Association (APHA): Washington, DC, USA, (2005).

[33] Y. Park, S. Park, V.K. Nguyen, J. Yu, C.I. Torres, B.E. Rittmann, T. Lee, Complete nitrogen removal by simultaneous nitrification and denitrification in flat-panel air-cathode microbial fuel cells treating domestic wastewater, Chem. Eng. J., 316 (2017) 673-679. [34] A. Sotres, M. Cerrillo, M. Viñas, A. Bonmatí, Nitrogen removal in a two-chambered microbial fuel cell: establishment of a nitrifying-denitrifying microbial community on an intermittent aerated cathode, Chem. Eng. J., 284 (2016) 905-916.

[35] H. Huang, D. Xiao, R. Pang, C. Han, L. Ding, Simultaneous removal of nutrients from simulated swine wastewater by adsorption of modified zeolite combined with struvite crystallization, Chem. Eng. J., 256 (2014) 431-438.

[36] X. Chen, H. Zhou, K. Zuo, Y. Zhou, Q. Wang, D. Sun, Y. Gao, P. Liang, X. Zhang, Z.J. Ren, Self-sustaining advanced wastewater purification and simultaneous in situ nutrient recovery in a novel bioelectrochemical system, Chem. Eng. J., 330 (2017) 692-697. [37] M. Hermassi, C. Valderrama, J. Dosta, J. Cortina, N.H. Batis, Evaluation of hydroxyapatite crystallization in a batch reactor for the valorization of alkaline phosphate concentrates from wastewater treatment plants using calcium chloride, Chem. Eng. J., 267 (2015) 142-152. 
[38] J. Liu, X. Cheng, X. Qi, N. Li, J. Tian, B. Qiu, K. Xu, D. Qu, Recovery of phosphate from aqueous solutions via vivianite crystallization: Thermodynamics and influence of $\mathrm{pH}$, Chem. Eng. J., 349 (2018) 37-46.

[39] R.D. Cusick, B.E. Logan, Phosphate recovery as struvite within a single chamber microbial electrolysis cell, Bioresour. Technol., 107 (2012) 110-115.

[40] D. Xiao, H. Huang, P. Zhang, Z. Gao, N. Zhao, Utilizing the supernatant of waste sulfuric acid after dolomite neutralization to recover nutrients from swine wastewater, Chem. Eng. J., 337 (2018) 265-274.

[41] Z. Wu, S. Zou, B. Zhang, L. Wang, Z. He, Forward osmosis promoted in-situ formation of struvite with simultaneous water recovery from digested swine wastewater, Chem. Eng. J., 342 (2018) 274-280.

[42] Y. Luo, H. Li, Y.-R. Huang, T.-L. Zhao, Q.-Z. Yao, S.-Q. Fu, G.-T. Zhou, Bacterial mineralization of struvite using $\mathrm{MgO}$ as magnesium source and its potential for nutrient recovery, Chem. Eng. J., 351 (2018) 195-202.

[43] F. Zhang, K.S. Brastad, Z. He, Integrating forward osmosis into microbial fuel cells for wastewater treatment, water extraction and bioelectricity generation, Environ. Sci. Technol., 45 (2011) 6690-6696.

\section{Feasibility study on a double chamber microbial fuel cell for nutrient recovery from}

\section{municipal wastewater}

\section{Figure captions}

Figure 1. Schematic representation of nutrients accumulation using a double-chamber MFC at different operation modes of the anode chamber. In this figure, CEM represents the cation 
exchange membrane; 1 represents the anaerobic microorganisms. Only cations such as proton and ammonium ions can freely transfer through the CEM between the anode chamber and cathode chamber.

Figure 2. Schematic representation of double-chamber MFC for nutrients recovery. CEM represents the cation exchange membrane; represents the anaerobic microorganisms. The nutrients recovery was explored while using the anode effluent as the influent of cathode chamber.

Figure 3. Ammonium accumulation in the cathode chamber in the: (a) batch mode; (b) selfcirculation mode; and (c) single-continuous mode. The ammonium accumulation in the catholyte is mainly driven by current field derived from the energy recovery in the wastewater. Figure 4. Changes in nutrient concentration in the: (a1) anode effluent with aeration supplied in catholyte; (a2) anode effluent without aeration supplied in catholyte; (b1) cathode effluent with aeration supplied in catholyte; (b2) cathode effluent without aeration supplied in catholyte. Figure 5. (a) EDS and (b) SEM image of the precipitates achieved in the cathode chamber in the double-chamber MFC

Figure 6. Remoyals of $\mathrm{NH}_{4}{ }^{+}-\mathrm{N}$ and $\mathrm{PO}_{4}{ }^{3-}-\mathrm{P}$ using double-chamber $\mathrm{MFC}$ with different separators. In this figure, CEM represents the cation exchange membrane; FO represents the forward osmosis.

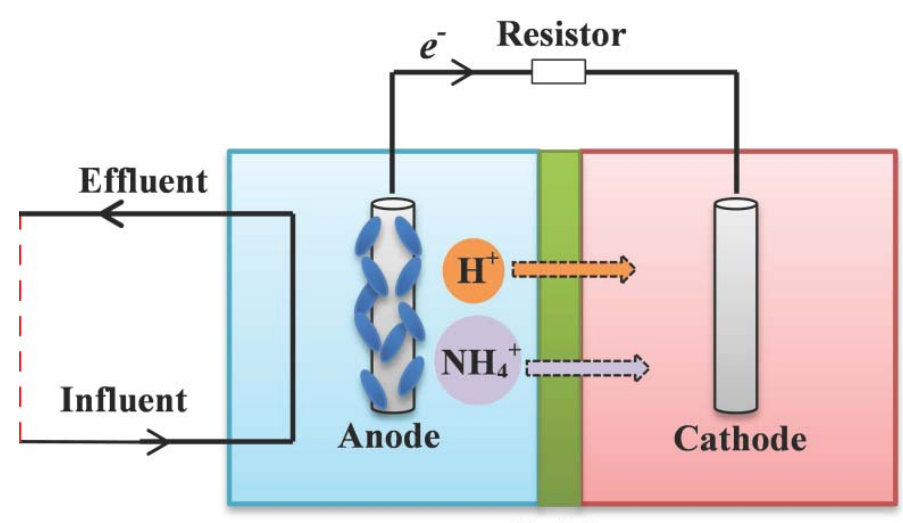

CEM 
Fig. 1

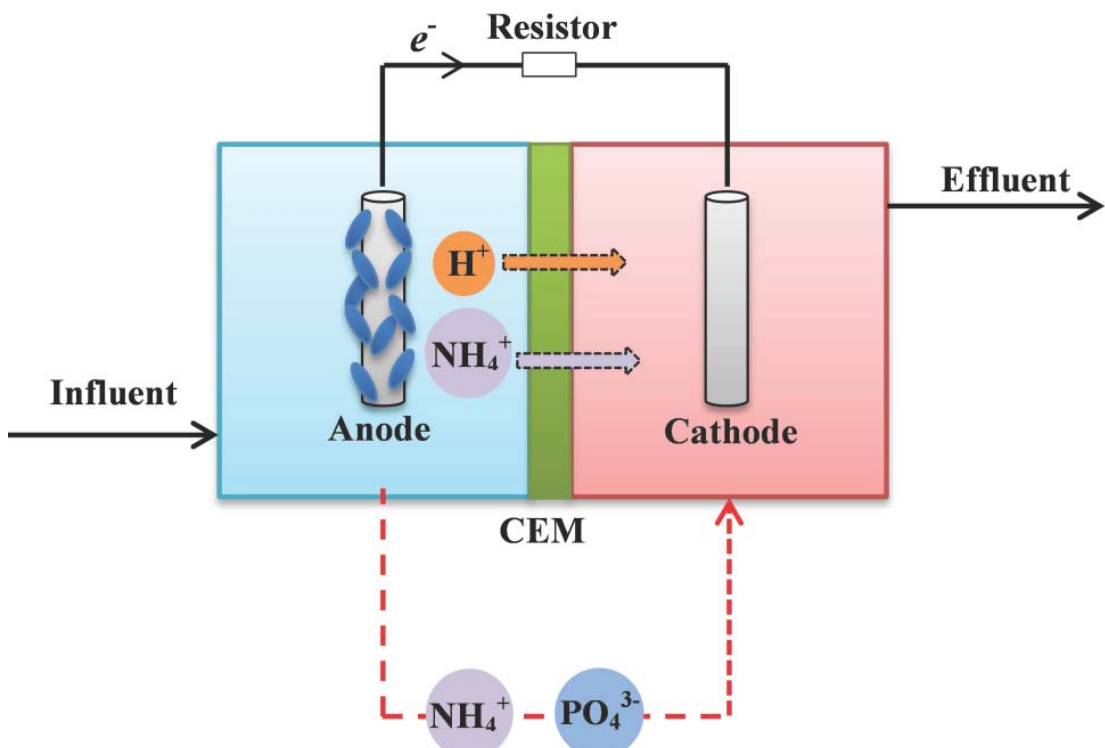

Fig. 2

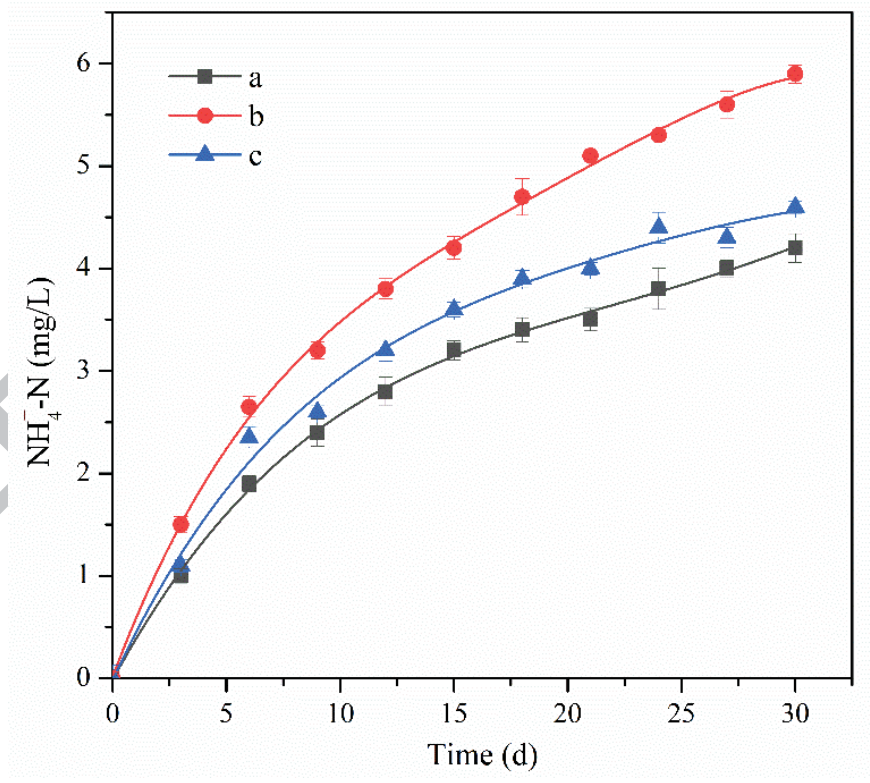

Fig. 3 

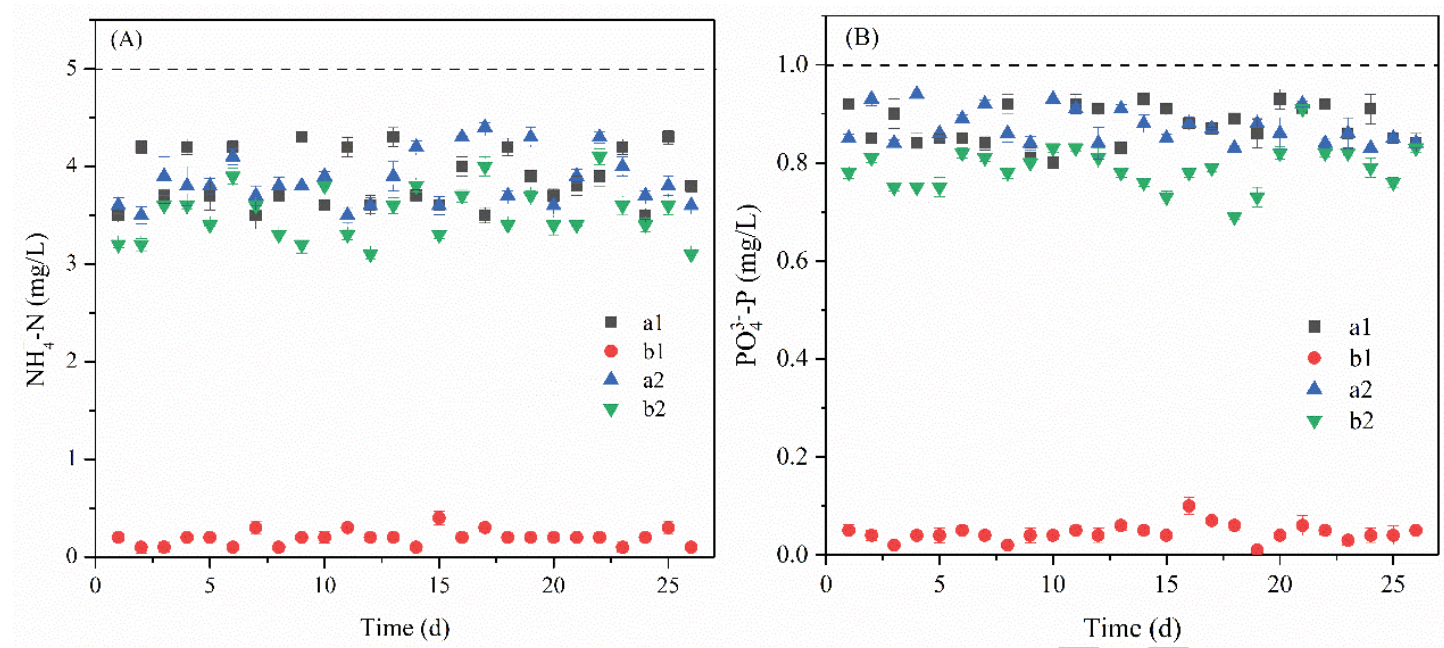

Fig. 4
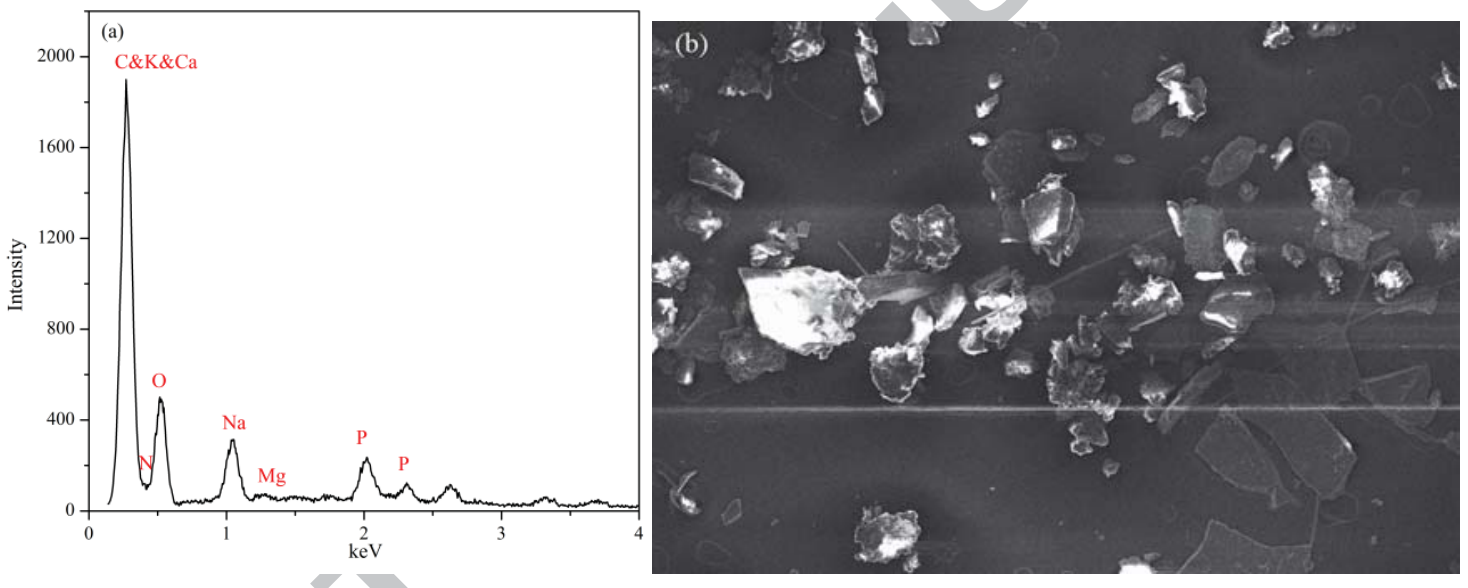

Fig. 5

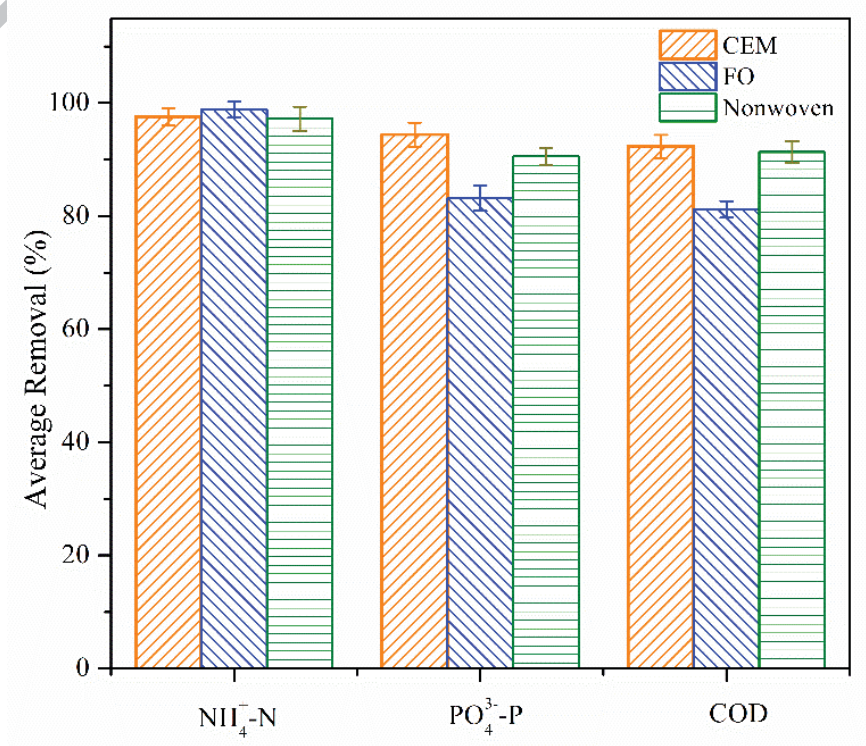

Fig. 6 